\title{
THE MARINE BIOLOGICAL ASSOCIATION OF THE UNITED KINGDOM
}

The Association was founded in 1884 to promote accurate researches leading to the advancement of zoological and botanical science and to an increase in our knowledge of the food, life, conditions and habits of British fishes. The work of the Association is controlled by a Council elected annually by its subscribing members.

Professor T. H. Huxley took the chair at the initial meeting held in the rooms of the Royal Society and was elected the first President. Among those present were Sir John Lubbock (afterwards Lord Avebury), Sir Joseph Hooker, Professor H. N. Moseley, Mr G. J. Romanes, and Sir E. Ray Lankester who, after Professor Huxley, was for many years president of the Association. It was decided to build a laboratory at Plymouth, where a rich and varied fauna is found.

The Plymouth Laboratory was opened in June 1888, and, since that date, considerable additions have been made to the buildings, including a library, lecture-hall, and extensive laboratory accommodation with up-to-date equipment. Additional sea-water reservoirs have also been built, and an aquarium, modernized in 1959, opened to the public.

Since its foundation the Association has been supported by subscriptions and donations from private members, universities, learned societies, the Fishmongers' Company and other public bodies. For some time past, however, the main financial support for the work of the Plymouth Laboratory has come from Government funds, and since 1965 the Laboratory has been grant-aided through the Natural Environment Research Council.

The Marine Biological Association, under the direction of its Council, undertakes research in all branches of marine science and the main results are published in this journal. Accounts of the laboratory and aquarium are to be found in Vol. 27 (p. 761), Vol. 39 (p. 391) and Vol. 43 (p. 281), and summaries of the activities and research of the Association are given annually in the Report of the Council in the November issue of the Journal.

The laboratory is open throughout the year and its work is carried out by a fully qualified research staff under the supervision of the Director. The names of the members of the staff will be found on the inner page of the front cover. Accommodation is available for British and foreign scientific workers who wish to carry out independent research in all branches of marine science. Arrangements are made for courses for advanced students, and marine animals and plants are supplied to educational institutions.

Work at sea is undertaken by three research vessels and by a motor boat, and these also collect the specimens required in the laboratory.

\section{TERMS OF MEMBERSHIP}

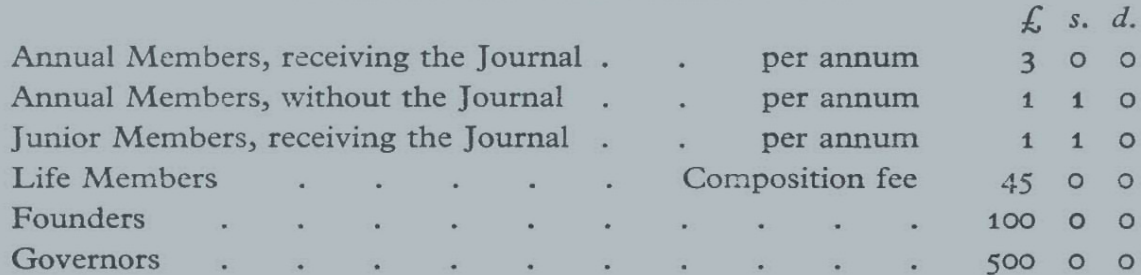

Members of the Association have the following rights and privileges: they elect annually the Officers and Council; they are entitled to receive the Journal of the Association at a much reduced rate; they are admitted to view the laboratory at Plymouth, and may introduce friends with them; they have the first claim to rent a place in the laboratory for research, with use of tanks, boats, etc; they have the privilege of occupying a table for one week in each year free of charge; and they have access to the books in the library at Plymouth.

The Commissioners of Inland Revenue have approved the Association for the purposes of Section 16, Finance Act, 1958, and that the whole of the annual subscription paid by a member who qualifies for relief under the section will be allowable as a deduction from his emoluments assessable to income tax under Schedule E.

All correspondence should be addressed to the Director, The Laboratory, Citadel Hill, 


\title{
CONTENTS
}

GREY, JOHN S. and RIEGER, REINHARD M. A quantitative study of the meiofauna of an exposed sandy beach, at Robin Hood's Bay, Yorkshire . . . . . .

MORRIS, ROBERT J. Seasonal and environmental effects on the lipid composition of Neomysis integer.

Foxton, P. A new species of the Genus Acanthephyra [Crustacea: Natantia]: first discovered and described in MS notes by Dr Stanley W. Kemp

Phillips, Graham. Incubation of the English Prawn Palaemon serratus

FretTer, Vera and Pilkington, MARgaret, C. The larval shell of some prosobranch gastropods

Riley, J. P. and Roth, Igal. The distribution of trace elements in some species of phytoplankton grown in culture .

FORSTER, G. R. Line-fishing on the continental slope. III. Mid-water fishing with vertical lines. . . . . . . . . . . . .

LOCKET, N. A. Retinal structure in Platytroctes apus, a deep-sea fish with a pure rod fovea . . . . . . . . . . . . . . . .

POLlOCK, LELAND, W. On some British marine Tardigrada, including two new species of Batillipes

SNow, N. B. and Williams, P. J. LeB. A simple method to determine the $\mathrm{O}: \mathrm{N}$ ratio of small marine animals

ANDrews, P. and Williams, P. J. LE B. Heterotrophic utilization of dissolved organic compounds in the sea. III. Measurement of the oxidation rates and concentrations of glucose

RUSSELL, F. S. and DEMIR, NECLA. On the seasonal abundance of young fish. XII. The years $1967,1968,1969$ and 1970 .

SEGAR, D. A., Collins, J. D. \& RiLey, J. P. The distribution of the major and some minor elements in marine animals. Part II. Molluscs

LEACH, J. H. Hydrology of the Ythan Estuary with reference to distribution of major nutrients and detritus

JoNeS, P. G. W. and FolKaRD, A. R. Hydrographic observations in the Eastern Irish Sea with particular reference to the distribution of nutrient salts

TETT, P. B. The relation between dinoflagellates and the bioluminescence of sea water .

LEADBEATER, B. S. C. Observations by means of ciné photography on the behaviour of the haptonema in plankton flagellates of the Class Haptophyceae

Bone, Quentin. On the Scabbard Fish Aphanopus carbo.

TAYLOR, D. L. Ultrastructure of the 'zooxanthella' Endodinium chattonii in situ

The subscription price of the Journal to non-members of the Association is $£ 22.00$ net a volume of four parts, post free, or $\$ 70.00$ in U.S.A., payable in advance. Subscriptions may be sent to any bookseller or to the Cambridge University Press, and in U.S.A. to the Cambridge University Press American Branch.

\author{
CAMBRIDGE UNIVERSITY PRESS \\ BENTLEY HOUSE, 200 EUSTON ROAD, LONDON, NW1 2 DB \\ AMERICAN BRANCH: 32 EAST 57 TH STREET, NEW YORK, N.Y.10022
}

Printed in Great Britain at the University Printing House, Cambridge 